compression of the foetus and that mechanical factors must be considered amongst the causes of congenital abnormalities of the limbs.

\section{Acknowledgment}

I would like to thank Mr J. R. Armstrong for permission to publish this case.

\section{References}

BROOKES, M. (1960) Sequelae of experimental partial ischaemia in long bones of the rabbit. J. Anat. (Lond.), 94, 552.

Browne, D. (1936) Congenital deformities of mechanical origin. Proc. R. Soc. Med. 29, 1409.

RING, P.A. (1959) Congenital shortening of the femur. $J$. Bone Jt Surg. 41 B, 73.

RING, P.A. (1961) Congenital abnormalities of the femur. Arch. Dis. Child. 36, 410.

\title{
A case of oat-cell carcinoma of the lung with the carcinoid syndrome
}

\author{
M. GovindaraJ \\ M.B., B.S. (Madras), M.R.C.P. (Glasgow) \\ Medical Registrar, Western Group of Hospitals, Glasgow \\ Formerly Senior House Physician, Western Hospital, Seagrave Road, London, S.W.6
}

IT IS Now well recognized that malignant neoplasms sometimes give rise to various syndromes by causing over-secretion of hormones. One of the most interesting of these is the carcinoid syndrome which is usually due to excessive serotonin or 5-hydroxytryptamine (5-HT). This has been described in association with carcinoma of the pancreas (Peart et al., 1963), thyroid (Moertel et al., 1965) and islet-cells (Van der Sluys et al., 1964). Williams \& Azzopardi (1960) were the first to record a proved case of carcinoid syndrome caused by an oat-cell carcinoma of the lung though Harrison et al. (1957) had previously observed some features of the syndrome in a patient with this carcinoma. Gowenlock et al. (1964) reported another case, but with a slight difference in that the tumour produced 5hydroxytrytophan (5-HTP) instead of 5-HT. Azzopardi \& Bellau (1965) added a third case and there were two more described by Majcher et al. (1965) one of which had an oat-cell carcinoma and the other an undifferentiated one. The following is a report on a case which is probably the sixth recorded so far.

\section{Case report}

Mr H.S., a 45-year-old warehouse porter, first saw his doctor in April 1967 because of moderately severe, persistent burning pain in his right foot. This was his only symptom. He was a married man with four children and had had no previous illnesses. There was nothing significant in the family history. He smoked fifteen to twenty cigarettes a day and was a teetotaller. $\mathrm{He}$ was sent to another hospital as an outpatient. After X-rays of his lumbar spine and pelvis he was given a low spinal brace and was instructed to wear it. But the pain persisted and soon involved the other foot as well. However, he was able to continue his work, lifting heavy parcels. Towards the end of May 1967 he developed a macular rash over his legs below the knees but this disappeared in a few days. The following month he went to see his doctor again and complained of a slight cough and tiredness in addition to the pain in the feet. He was now also having bouts of diarrhoea over periods of 3-4 days with four or five stools per day. An X-ray of the chest showed a faint ill-defined opacity in the right lower zone and the patient was admitted to the Western Hospital on 11 July 1967.

His chief complaint still was the burning pain in the feet. It was constant, with no aggravating factors, and was occasionally severe enough to wake him up from sleep. He had no breathlessness but complained of feeling weak in the legs on walking about $100 \mathrm{yd}$. He had no diarrhoea at the time but had had several bouts of it at home. He had lost a few pounds in weight.

On examination he appeared fairly well. There was marked telangiectasia of the face. The skin over the feet and ankles was erythematous, rough and somewhat scaly. There was no finger clubbing or joint swelling and no lymph glands were palpable. Pulse regular, $88 / \mathrm{min}$, and BP $180 /$ $100 \mathrm{mmHg}$. All peripheral pulses were felt. Heart sounds were normal and there were no murmurs. The percussion note was impaired and breath sounds diminished over the right lower chest posteriorly. The liver was enlarged to just below the umbilicus and was nodular and slightly tender. There was no abnormality in the central 
nervous system apart from a doubtful impairment of light touch perception over the toes. Muscle tenderness was absent.

Investigations. $\mathrm{Hb} 12 \mathrm{~g} / 100 \mathrm{ml}$. ESR $40 \mathrm{~mm} / \mathrm{hr}$ (Westergren). Urine, no abnormality. Blood urea, $26 \mathrm{mg} / 100 \mathrm{ml}$. Serum electrolytes; sodium 138 $\mathrm{mEq} / 1$ potassium, $4.1 \mathrm{mEq} / 1$; chloride, $98 \mathrm{mEq} / 1$; bicarbonate, $24 \mathrm{mEq} / 1$; Serum proteins, $6.5 \mathrm{~g} /$ $100 \mathrm{ml}$; albumin, $2.9 \mathrm{~g}$; globulin, $3.6 \mathrm{~g}$ with an increase in the $\alpha_{1}, \alpha_{2}$ and $\beta$ fractions. Serum bilirubin, $0.6 \mathrm{mg} / 100 \mathrm{ml}$; glutamic oxalacetic transaminase, $46 \mathrm{u} / \mathrm{ml}$; alkaline phosphatase, $120 \mathrm{u} /$ $100 \mathrm{ml}$; 5-nucleotidase, $104 \mathrm{u} / 1$. Chest X-ray showed a slightly elevated right dome of the diaphragm and a faint horizontal shadow just above it measuring $2.5 \times 1 \mathrm{~cm}$ with ill-defined borders. The elevation of the diaphragm was not surprising in view of the hepatomegaly. Two collections of 24-hr urine were made and the 5-hydroxy indole acetic acid (5-HIAA) contents were $37 \cdot 4$ and $36 \mathrm{mg}$, which suggested a carcinoid syndrome. Six specimens of sputum were examined for malignant cells but none was found. A barium meal was done to exclude a lesion in the gastrointestinal tract and no abnormality was seen. A bronchoscopy (Dr L. J. Grant) showed that the right main bronchus was narrowed to a slit and the mucosa was thickened and haemorrhagic. The appearances were highly suggestive of a carcinoma. Histology of the biopsy specimens confirmed the diagnosis of carcinoma of the oatcell variety.

During the period of investigations the patient's condition steadily deteriorated. The pain in the feet persisted. Four weeks after admission to hospital he developed oedema of the feet without any other sign of heart failure. Deterioration was rapid after this and he died on 31 August 1967.

Necropsy. The right main bronchus was found to be surrounded by a cuff of tumour mass which was histologically an oat-cell carcinoma. Metastatic carcinoma was found in the carinal, mediastinal and upper para-aortic lymph glands, both kidneys, thyroid and the adrenals. A small subpleural deposit was seen in the other lung also. There were no obvious secondary lesions in the brain or bones. The heart weighed $395 \mathrm{~g}$ and showed some left ventricular hypertrophy. The valves were normal. The coronary arteries and the aorta showed moderate atheromatous changes. The gastro-intestinal tract was completely normal. There was some free fluid in the peritoneum.

\section{Discussion}

This patient had some clinical features of the carcinoid syndrome. The diagnosis was confirmed by the elevated 5-HIAA levels in the urine (normal $<10 \mathrm{mg} / 24 \mathrm{hr}$ ) though these are often 3 much higher in this condition. As it happened $\stackrel{\varnothing}{\circledR}$ there was an interval of more than 2 days be- $c$. tween the collection of urine and the estimation $\vec{F}$ and without this delay the figures for 5-HIAA $\stackrel{?}{\rightarrow}$ might have been higher. In view of the patient's? poor condition a much fuller investigation was $\frac{\bar{c}}{\bar{c}}$ not feasible.

Diarrhoea and telangiectasia are usual features $\stackrel{\mathbb{Q}}{\circ}$ of the condition together with flushes, wheezing and right heart valvular lesions. The pellagra- $\vec{\circ}$ like dermatitis is not so common and is believed to be the result of diversion of dietary tryptophan $\vec{\omega}$ into the serotonin pathway with a consequent $\frac{\text { s }}{\circ}$ fall in niacin formation. The burning pain is also a feature of pellagra and indeed has been described in patients with carcinoid disease (Clinico-Pathological Conference, Brit. med. J., or 1963). However, it is unusual for it to be the presenting symptom. Pain of this nature in $\frac{\infty}{c}$ patients with carcinoma of the lung has been occasionally attributed to hypertrophic pulmonary osteo-arthropathy even before the character- $\overrightarrow{0}$ istic clinical and radiological picture develops. Cases of carcinoid syndrome caused by oat cell $\frac{0}{0}$ carcinoma may not be as rare as the paucity of $\mathbb{Q}$ reports suggests and it would seem to be wortli $\vec{\varphi}$ while bearing this complication in mind.

\section{Acknowledgment}

I am grateful to Dr L. J. Grant, Consultant Physician, Chelsea and Kensington Hospital Group, for permission to publish this case and for advice in preparing this report.

\section{References}

Azzopardi, J.G. \& BellaU, A.R. (1965) Carcinoid syndrome and oat-cell carcinoma of the bronchus. Thorax, 20, 393.

Clinico-Pathological Conference (1963) A complicated case of carcinoid disease. Brit. med. J. i, 1397.

Gowenlock, A.H., Platt, D.S., Campbell, A.C.P. \& WORMSLEY, K.G. (1964) Oat-cell carcinoma of the bronchus secreting 5-hydroxytryptophan. Lancet, i, 304.

HARrison, M.T., MONTGOMERY, D.A.D., RAMSEY, A.S., Robertson, J.H. \& Welbourn, R.B. (1957) Cushing's syndrome with carcinoma of bronchus and with features suggesting carcinoid tumour. Lancet, i, 23.

MajCher, S.J., Lee, E.R., Reingold, I.M., Boyle, J. \& HAVERBACK, B.J. (1966) Carcinoid syndrome in bronchogenic carcinoma. Arch. intern. Med. 117, 57.

Moertel, C. G., Beahrs, O. H., Woolner, L. B. \& TyCe, $>$ G.M. (1965) Malignant carcinoid syndrome associated with non-carcinoid tumours. New Engl. J. Med. 273, 244.

Peart, W.S., Porter, K.A., Robertson, J.I.S., Sandler, M. o \& BALDOCK, E. (1963) Carcinoid syndrome due to pancreatic duct neoplasm secreting 5-hydroxytryptophan and 5-hydroxytryptamine. Lancet, i, 239.

Van Der Sluys Veer, J., Choufder, J.C., Querido, A., VAN Der Heul, R.O., Hollander, C.F. \& VAN Riussel, T.G. (1964) Metastasising islet-cell tumour of the pancreas associated with hypoglycaemia and carcinoid syndrome. Lancet, i, 1416.

Williams, E.D. \& Azzopardi, J.G. (1960) Tumours of the lung and the carcinoid syndrome. Thorax, 15, 30. 